Eurasia: Economics \& Business, 1(19), January 2019

DOI https://doi.org/10.18551/econeurasia.2019-01

UDC 330

\title{
A NEW METHODOLOGY TO INITIATE ISLAMIC POLITICAL ECONOMY OF ACCOUNTING
}

\author{
Sokarina Ayudia \\ University of Mataram, West Nusa Tenggara, Indonesia \\ Triyuwono Iwan, Irianto Gugus, Ghofar Abdul \\ University of Brawijaya, Indonesia \\ *E-mail: ayudia.sokarina@gmail.com
}

\begin{abstract}
This paper aims to develop a new methodology to initiate Islamic Political Economy of Accounting (IPEA). The data involved in this study were in the form of textual data of HOS Tjokroaminoto, Ibn Taimiyah and Iwan Triyuwono. The textual data consisted of their own writings and thoughts written by others. The new methodology based on the results of this study is called the Islamic Reasoning Trilogy. This methodology merges literalistic thinking of Ibn Taimiyah, contextual thinking of HOS Tjokroaminoto, and intuitive thinking of Iwan Triyuwono. Thus, the resulting IPEA concept is originated from a unified Islamic way of thinking which always rests on the value of Tawheed. This result is recommended for researchers (practitioners, academics and students) who want to develop the concept of Islamic Political Economy of Accounting by using a comprehensive analysis that is literalistic, contextual and intuitive.
\end{abstract}

\section{KEY WORDS}

Methodology, islamic economics, political economy, accounting.

The IPEA concept in this study is a concept built on the criticism of classical PEA ${ }^{1}$. The previous classic PEA researchers from Amir et al. (2014); Noch (2013); Abdelrehim et al., (2012); Haryadi (2011); Sokarina (2011); Andrianto and Irianto (2008); Irianto (2004); Uddin and Hopper (2003); Shaoul (1997a, 1997b, 2003) generally interpret PEA in a micro basis. Despite the development carried out by several researchers (Amir et al., 2014; Sokarina, 2011; Andrianto \& Irianto, 2008), PEA is employed as a methodology. Conversely, when interpreting PEA on a macro basis, it means placing PEA as a framework for reducing accounting theory from the dominance of neoclassical economic values and then replaced by classical political economic theory (Andrianto \& Irianto 2008).

IPEA itself is a concept that frees the accounting from the dominance of both neoclassical and classical political economy. Classical political economy as a classic PEA foundation provides two traps in accounting, materialism and homo sociologicus. Materialism derives from the historical root of PEA which was born from the concept of historical materialism by Marx (Tinker et al., 1982; Roslender, 1992). The concept of historical materialism views materialism as a matter of human involvement in the economic process and the way it is produced (Kristeva 2011). Human social conditions are focused on their production and work. Humans are determined by their production, both what they produce, and how they produce. Therefore, individuals depend on the requirements of their production material (Suseno, 2010).

On the other hand, PEA comes from the root of the ideology of socialism. It was started from Marx's attention to human freedom and then he tried to find answers to problems so that people are not socially alienated. The exemption from alienation and from the

\footnotetext{
1 The use of the term classical PEA refers to the explanation of Andrianto and Irianto (2008), namely PEA introduced by Tinker (1980).
} 
exploitation of people by people can only be achieved if personal rights are removed. A state without personal rights is called socialism (Suseno, 2010; Souza, 2007; Kristeva, 2011).

The human model derived by socialism is homo sociologicus (Jensen \& Meckling, 1994). Jensen \& Meckling (1994) revealed that the human model of homo sociologicus does not focus solely on material income but also cares for the social environment, psychological needs and the interests of society.

Both materialism and homo sociologicus are the form of neglect of invisible reality. As Marx agreed to Feuerbach's idea that God, angels, heaven, and hell do not have reality in themselves, but only images formed by humans about themselves, so it is human imagination about its own nature (Suseno, 2010). The undeniable reality is only sensory experience not speculative experience like religion as affirmed in the Qur'an: "And they say: there is not but our worldly life; we die and we live and nothing destroys us except time (QS. Al Jasiyah 45: 24). Likewise in another surah it is said that "they know what is apparent of the worldly life, but they, of the Hereafter, are unaware (QS. Ar Rum 30: 7). "

Islam can contributes to the achievement of the balance of visible and invisible reality because of its ability to foster a holistic approach to life (Kamla 2009). Life that reflects the principle of unity between the world and hereafter becomes a single system that lives and is embedded in the mind of every individual, without any separation between amaliah and ukhrawi, and it does not have definite core even though it is different in the way it takes (Quthb, 1994).

Thus, IPEA concept requires a methodology that emphasizes wholeness of thinking as IPEA makes tawheed as its social reality. Tawheed is not only the first part in the testimony of the Islamic faith but also a statement of knowledge about reality (Bakar, 2008).

\section{LITERATURE REVIEW}

Philosophy Building of Islamic Political Economy of Accounting. The philosophy building of IPEA is built on criticism of the assumption of the classic PEA philosophy. PEA's foundation is historical materialism (Tinker et al., 1982) which acts as an epistemology or ontology (Hidayat, 2013). The assumption of IPEA ontology is monotheism or tawheed (see table 1). Tawheed is the first part of the witnesses of Islamic faith which is reflected in the sentence la ilaha Illallah (there is no God but Allah S.W.T) as a statement of knowledge about reality (Bakar, 2008: 67). On other hand, Faruqi (1992) said that tawheed is not only able to express reality but also able to express truth, world, space and time, human history and even destiny.

Tabel 1 - PEA and IPEA Philosophical Assumptions

\begin{tabular}{|l|l|l|l|}
\hline & Philosophical Assumption & PEA & IPEA \\
\hline 1 & Ontology & Historical Materialism & Tawheed \\
\hline 2 & Epistemology & Historical Materialism & Islam \\
\hline 3 & Human Nature & Homo Sociologicus & Homo Islamicus \\
\hline 4 & Methodology & PEA & Islamic Reasoning Trilogy \\
\hline
\end{tabular}

Source: created from Burrell \& Morgan (1979).

The extent of the nature of monotheism shows that there is an integration between the awareness of the oneness of God with science. This awareness of the oneness of God strengthens the truth that God is one in His essence, in His names and attributes, and in His actions. As the consequence of exposing the reality of the universe, Islam recognizes that the cosmos consists of various levels of reality, not just physical. All levels of reality form unity because they are manifestations of the only source and metaphysical origin namely God (Bakar, 2008).

Related to the nature of the ontology, tawheed as a pure form brings consequences for the epistemology. With regard to its Divine origins which is knowledge of noumena which links phenomena to their true origins as the source of all existence (Bakar, 2008: 96-97). 
The highest source of knowledge in Islam is Wahy, the Qur'an. Qur'an is a complete and sufficient source of human knowledge.

The Qur'an gives honor to humans ${ }^{2}$ in three ways: (1) man is referred to in the context of dealing with Allah S.W.T., as a being made from a lump of blood; (2) humans are referred to in the context of dealing with God as a being who receives a lesson or knowledge through the means of a tool, al-qalam (pen), or writing instrument; and (3) Al Qur'an mentions a process of moving from a state of ignorance to knowing. The meaning of man is not just as a biological being but also a spiritual being who receives knowledge from Allah, a learning being (Rahardjo, 2005).

Based on the understanding of humans, homo Islamicus model is a human model that goes beyond the homo economicus model and homo sociologicus model. This shows that homo Islamicus model is the best human model compared to Resourceful, Evaluative, Maximizing Model (REMM) which is believed to be the best human model by Jensen \& Meckling (1994). Five human models according to Jensen \& Meckling (1994) are REMM, Economic Model (or Money Maximising Model), The Sociological Model (or Social Victim Model), The Psychological Model (or Hierarchy of Needs Model), and The Political Model (or Perfect Agent Model) which are classified into two, namely model one and two as homo economicus and the last three models as homo sociologicus (Triyuwono, 2015).

PEA as a methodology reflects materialistic usefulness as summarized by several researchers regarding the function of PEA. A research from (Andrianto \& Irianto, 2008: 4647) mentioned three functions of PEA. First, PEA is used to criticize the company's performance internally and its relationship to the state and global power structure. Second, PEA provides a description of political economic relations based on accounting data from various companies in a country or across countries as well as used to see the distribution of welfare for economic activities that have an effect on company activities. Third, PEA has a big role in restructuring accounting theory more rationally and easily.

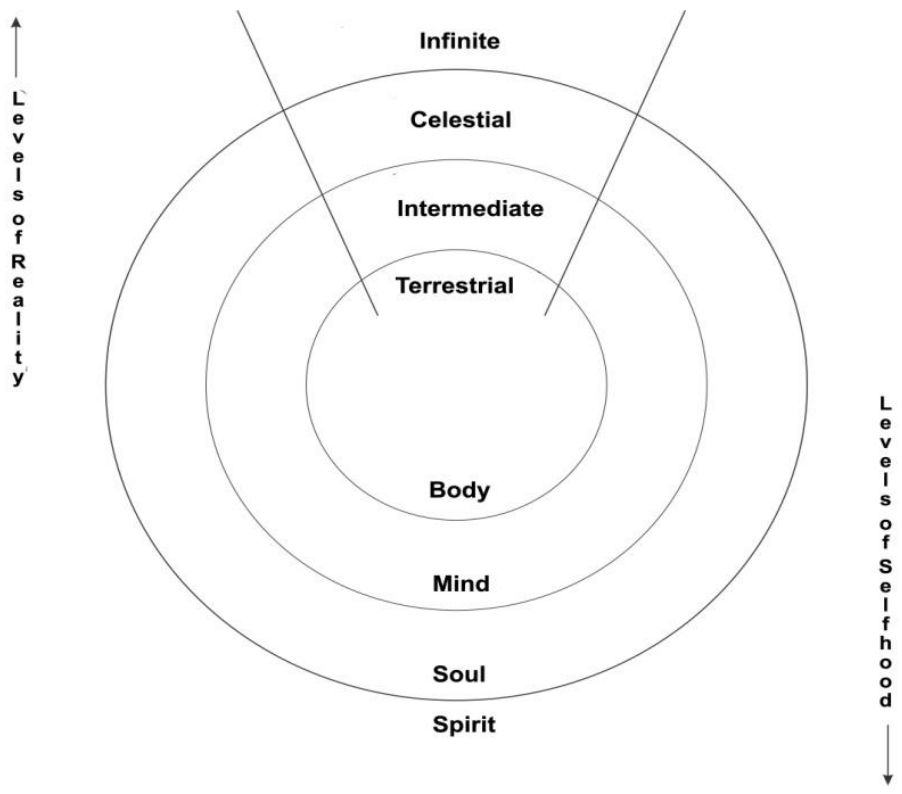

Figure 1 - The correspondence of each level of the macrocosm and microcosm (Source: images produced from Forgotten by Huston Smith quoted from Bakar, 2008)

Furthermore, a research from Cooper \& Sherer (1984) also mentions the characteristics of PEA, among others (1) PEA acknowledges the existence of power and conflict in the community towards the company's performance, (2) PEA tries to explore the specific history and rules of the game (institutional) where accounting is practiced, (3) PEA

\footnotetext{
${ }^{2}$ Surah Al'Alaq (96) 1-5: Recite in the name of your Lord Who created man from a clot of congealed blood, and your Lord is Most Generous, Who taught by the pen, taught man what he did not know.
} 
recognizes that the accounting function is dynamic in society, because accounting is not free from emancipative human motivation. As added by (Sokarina, 2011), the use of PEA (4) especially in developing countries is to pay attention to structural changes in the global and domestic economy which shift the balance of forces between different interests (foreign and local), and create a conducive political climate for accounting changes (Rosser 1999), (5) PEA explores the rationality of each individual in meeting needs, both as part of efforts to accumulate capital owners' wealth or attempt to legitimize the political economy system (Andrianto and Irianto, 2008; see also Rosser, 1999), and (6) PEA aims to understand the economic conditions of countries where accounting is practiced in order to ensure a fair level of community welfare (Andrianto and Irianto, 2008).

On the contrary, IPEA methodology has principles that cover the subjective knowledge and objective knowledge. Both of these knowledge can represent the relationship between the level of human and the level of reality and the principles governing the relationship between the two (Bakar, 2008). As explained in Figure 1, the achievement of the body level in the human will capture material reality. Likewise, the achievement of mind will capture the intermediate reality. At the level of self, soul will grasp the celestial reality. Then, the highest achievement of spirit will capture the absolute reality that is infinite.

\section{METHODS OF RESEARCH}

This study did not specifically take research sites as the basis for empirical data collection. However, this study emphasized more on developing a new methodology for the IPEA concept which presented secondary data to support arguments. The reality of tawheed reflects the unity between the economic, political, accounting and Islamic realities. Based on the ontological understanding, the researcher had a freedom in determining the data and data analysis method.

Type and Method of Data Collection. This study involved textual data as the main data source. Although textual sources were additional or secondary data sources after word and action data sources (Moleong, 2008). Textual data sources were summarized from the thoughts of HOS Tjokroaminoto, Ibn Taimiyah and Iwan Triyuwono.

Data Analysis Method. The data analysis in this study was carried out by annotating the thoughts of three figures (authors), namely HOS Tjokroaminoto, Ibn Taimiyah and Iwan Triyuwono as stated in several of their works. The composition in annotating the works was based on Wijaya (2017); first, the researchers looked for academic anxiety why the authors poured their ideas into a book. Second, the researchers determined the problems and limitations which became the object of the study. Third, the researchers revealed and described scientific goals and contributions in order to determine the methodology. Lastly, the researchers looked for methods, approaches and theories used by the authors.

Based on the four steps above, it functioned as a logical thinking for the researchers in carrying out readings involving three parts: root or foundation, stem (content of research) and fruit or research results. Thus, the result of the annotation of these works was an objective description.

\section{RESULTS AND DISCUSSION}

Towards a New Methodology: Islamic Reasoning Trilogy. This section presents the results of the annotation process of each thought from HOS Tjokroaminoto, Ibn Taimiyah, and Iwan Triyuwono.

Thought of HOS Tjokroaminoto: Dialectics of Islamic Socialism. There is a way of reading that needs to be straightened out from the observers of the thought of HOS Tjokroaminoto which is developing in Indonesian society. An assessment of the notion of socialism that will bring communism to life brings implications for the scientific development of HOS Tjokroaminoto. Such assessment was born because it only sees the thought of HOS Tjokroaminoto as a discourse, and completely ignores his thought as a tool or method. 
Based on the history, the Islamic organization that appeared to move in the socioeconomic and socio-political field during the HOS Tjokroaminoto period was Sarekat Islam (SI). SI was the only national movement organization that first raised national awareness evenly to all levels of society from high, middle and ordinary class throughout the country, especially when SI held its first national congress in Bandung in 1916 (Amin, 1980).

In 1920, there was a split in the SI, between the rightist (SI members who were Muslim and later known as the White $\mathrm{SI}$ ) and leftist (SI members who were Marxists and better known as the Red SI) (Anshory \& Hendratno, 2015). The exciting debate between Haji Agus Salim-Abdul Muis representing White SI and Semaun-Tan Malaka representing Red SI resulted in elimination of Red SI from SI in 1912. Then, Red SI named itself as Sarekat Rakyat (SR). Moreover, the Dutch colonial government brought four Dutch communist figures: Sneefliet, Baars, Brandesder, and Van Burink to Indonesia. They were specifically assigned to recruit the best SI cadres: Semaun, Darsono, Alimin, and Tan Malaka to become communist cadres (Mulawarman, 2015).

This situation caused the SI leader, HOS Tjokroaminoto, to conduct a comparative study of the teaching of Islam and Marxism. In November 1924, a book entitled Islam and Socialism was published. That fact drove HOS Tjokroaminoto to think about socialism and Islam that differed greatly from the ideology of Marxism (Anshory \& Hendratno, 2015).

In order to make it easier for people to understand and distinguish between socialism and communism, HOS Tjokroaminoto identified the meaning of both perspectives. Communism is a gatherer (verzamelnaam) and socialism is a kind name (soortnaam). Communism is all the rules (stelsel) that attack; the nature of someone's possession and to replace it should be done based on communia boniorum or the items they want to be shared The imagination or communio bonorum thought always goes hand in hand with the word communism, and the arrangement of communio (having, having together), that becomes standard for communist ownership (Tjokroaminoto, 2010).

On the other hand, socialism is a part of communism, socialism or collectivism which according to this understanding is every rule concerning the affairs of property (economisch stelsel). In order to get a right understanding of the meaning of that word, HOS Tjokroaminoto warned that the meaning of socialism has two considerations. If socialism is defined as a regulation on matters of property, then it does not cover its teachings and philosophy. However, if socialism is based on the principles of philosophy or principles of religion, it is socialism that must be followed by Muslims (Tjokroaminoto, 2010).

HOS Tjokroaminoto approved limited socialism both in the form of concepts and praxis of Marx's socialism. However, at the same time he disagreed and had substantial differences with it; it was even more different from the developing ideologies and became the core value of the West, such as capitalism, let alone Chauvinism (Mulawarman, 2015). It means that HOS Tjokroaminoto rejects both historical materialism and capitalism as Islam rejects the historical materialism that holds that everything comes from things, to things and returns to things. While according to Islam, everything comes from Allah, to Allah and back to Allah. Capitalism is contrary to Islam because this understanding attaches great importance to individuals and it is greedy in the accumulation of wealth, regardless of social and humanitarian aspects.

Socialism must be based or work together with religious belief. If human action and thought are not guided or not observed by religious belief, then socialism will get lost and bring harm to human. Socialism can only be perfect if every human being does not live only for himself just like an animal or bird, but lives for the needs of the community together; because everything that exists is only derived or created by one might or one power, Allah the Almighty (Tjokroaminoto, 2010).

HOS Tjokroaminoto was not merely to Islamize Marx's socialism but he firstly made substantial criticism of socialism and even capitalism, and then proposed the Islamic way of socialism. Therefore the purposes of writing his book entitled Islam and Socialism (Amin, 1995) are as follows: 
- To build understanding and feelings of Muslims that Islam not only requires salvation for its adherents but also requires the salvation of all human relationship and humanity as a whole;

- To dismiss the false assumption that Islam is incapable of advancing matters relating to politics, economics and social.

Based on the above objectives, it is clear that the way Islamic socialism has the core to carry out peace and safety. In line with the interpretation of Islamic word identified by HOS Tjokroaminoto (Tjokroaminoto, 2010), Islam has four main meanings: Aslama, Salima, Salmi, and Sulami meaning submission, safety, harmony and stair.

The four meanings of Islam led HOS Tjokroaminoto to initiate two main principles of Islamic socialism, namely Islamic generosity and Islamic brotherhood. Generosity as a principle is not doing charity as a mere form of virtue, but charity is the obligation to gain the love of Allah. Generosity to achieve God's love will give three impacts. First, it places the people interest above personal interest in achieving contentment of Allah. Second, zakat is the basis for the distribution and even equalization of wealth for the entire community. Third, world poverty is not an insult, but the evil of the world is humiliation. The second principle, namely the brotherhood of Islam, emphasizes brotherhood that is built not based on ethnicity, color, race, wealth, or anything else, but based on piety (Tjokroaminoto, 2010).

Islamic socialism for HOS Tjokroaminoto is the perfection of socialism based on the assumption of human life for self as well as social relations that must rely on QS. 51: 56; human is a part of society, he does not only live in his own world, or just doing social activities as social people only. More than that, humans must have a higher purpose, devotion to Allah. In order to achieve the highest objective of humanity, HOS Tjokroaminoto called it as the achievement of humanity towards true life. The achievement of the true life of man is carried out in stages:

"(1) Knowing Allah through the path of truth and trust in Allah; (2) Studying the perfect beauty that only exists in Allah; (3) Proving the truth of the nature of Allah that is the Gracious; (4) Requesting primary help by only praying to Allah; (5) Distributing wealth, using all strength, and knowledge, sacrificing lives in the way of Allah; (6) Strengthening the heart for all tests and putting forward patience; (7) building social relations within the community of worship and perfection of examples; (8) Relying on signs and symbols of Allah's holiness (Tjokroaminoto, 2010)".

The explanation of the thought of HOS Tjokroaminoto above, actually confirms that Islamic socialism represents change and resistance to the tyranny of idols. That the highest power and might is with Allah, not others. Islam views human's main dependence only on Allah. Dependence on other parties means to stick to human strength. This is a form of fundamental error in thinking and acting. This means that dependence on humans, even on human products, causes the loss of the sanctity of Islam itself (Mulawarman 2015). This confirms the value of tawheed in the thought of HOS Tjokroaminoto (Amin, 1995).

Contextual Method as a Thinking Method of HOS Tjokroaminoto. Based on the explanation above, it can be said that the thought of HOS Tjokroaminoto is contextual. It is demonstrated by the way HOS Tjokroaminoto read Marx's thoughts in the context of Indonesian Islam. Contextual analysis is carried out as follows: (1) Identifying the meaning of the text on the issues highlighted as a result of literalistic analysis; (2) Linking the interpretation of the text to the liaison context (the context of HOS Tjokroaminoto) and the current context; and (3) Adopting relevant interpretations.

Realism and Empiricism Reasoning of Ibn Taimiyah. The reading of Ibn Taimiyah's thought has so far emphasized the ideal side which is permanent so that it shows the figure of Ibn Taimiyah as a rigid, hard-hearted person and only prioritizes religious formalism. Indeed, in Ibn Taimiyah's thought there are two sides: the ideal side is eternal and consistent and the socio-historical side is dynamic (Mauludi, 2012). For this reason, it is necessary to understand the principles and methodology of Ibn Taimiyah's thought so that a complete view can be obtained.

The essence of Ibn Taimiyah's thinking centers on a set of principles from which he develops a worldview. These principles are as follows: 
- Absolute difference between creator and creature;

- Revelation as a complete and sufficient system;

- The requirement to always return to the Qur'an and al-Sunnah, and understand it under the light of the teachings of the early generations of Muslims.

The first principle is a philosophical foundation concerning the position of Allah and humans that are absolutely different ontologically. This principle seems to be influenced by the polemic of Ibn Taimiyah by understanding wahdat al-wujud which relativizes the relationship between God and humans. The second principle is the foundation of epistemology concerning the position of revelation as a source of knowledge for humans that is complete and sufficient. This principle is influenced by the polemic of Ibn Taimiyah and Mu'tazilah's philosophers and rationalists who always put forward reason and did ta'wil. The third principle is an axiological basis concerning the actualization of Islamic teachings based on al-Qur'an, al-Sunnah and salaf al-shalih. This principle is influenced by the polemic of Ibn Taimiyah with various practices of Muslims, especially Sufi groups who have carried out various practices of heresy (bid'ah) (Mauludi, 2012).

The methodology of Ibn Taimiyah is a continuation of the literalist methodology of Ahmad ibn Hanbal and Daud al-Zhahiri. This methodology is characterized by strict submission to the verses of the Qur'an and Al-Sunnah (Madjid 1984) and the source of Islamic theology and law (Mauludi, 2012). Based on this principle, all religious issues must be returned to the Qur'an and wisdom of the Prophet and imitate the people of al-salaf alshalih. The impact of this principle prompted Ibn Taimiyah on literalism in understanding the scriptures and refused to do rational interpretations, especially those using foreign materials (not Islam). Borrowing the term al-Jabiri, Ibn Taimiyah's literalistic method can be included in the Bayani type of epistemology, which emphasizes textual explanations of nash. (Al-Jabiri, 2003). This literal methodology basically allows the text itself to speak so that the text will be isolated from subjectivity biases and radiate the original meaning.

Literalistic Method as the Thinking Method of Ibn Taimiyah. Literalistic analysis is a combination of empirical and ideal as obtained from the reading of the book Majmu 'Fatawa by Ibn Taimiyah. The empirical refers to the questions of the problem proposed to Ibn Taimiyah in the context of that time. On the other hand, the ideal means confirmation by Ibn Taimiyah on these problems based on the Qur'an and sunnah.

The literalistic analysis steps are as follows: (a) Employing bracketing method to bring out the purity of meaning, as in the steps of Ibn Taimiyah in answering questions of problems accompanied by opinions on various schools. He did not only put forward Ahmad Hanbali's school of thought, which in fact was the school of his extended family. So, Ibn Taimiyah could see and be a free mentality. (b) Synchronizing the opinions of Ibn Taimiyah which are spread in other chapters and even other volumes in the book of Majmu 'Fatawa. This is the process of discovering the essential meaning of the text; and (c) Synthesizing meaning.

Islamic Spirituality Reasoning of Iwan Triyuwono. The controversy over Iwan Triyuwono's thinking began when he used the teaching of Manunggaling Kawulo Gusti in the development of Islamic accounting in Indonesia. (Triyuwono, 2006; Triyuwono, 2012). The use of the teachings of Manunggaling Kawulo Gusti refers Sufism thought which actually comes from the Islamic tradition. As proposed by al-Jabiri, Arab epistemology consists of bayan, burhani and irfani y (Al-Jabiri, 2003). The thought of Iwan Triyuwono can be categorized into the irfani epistemology which puts the authority of truth on intuition. At that time even nowadays, the process of Islamization of accounting science in Indonesia still continued to process in accepting intuitive method.

Making the thought of Iwan Triyuwono as a method is a way to find certain dimensions of thought that have been missed by some observers of Iwan Triyuwono's thoughts so that they enter into unthinkable or forgotten areas. Besides being able to find a forgotten dimension, reading like this will also influence the assessment and attitude towards Iwan Triyuwono's thoughts.

There are three elements that are interrelated in science, namely: tools, objects and their relationship. The tools of science are senses, mind and intuition. This shows that the object of science includes concrete objects and abstract objects and their relationship means 
relationships in the form of achievement (Wijaya, 2017). Based on this element of knowledge, the results of reading Triyuwono's thoughts capture that the human process to know consists of two big things. First, human may know the belief method. Second, it doubts human who knows what is known as the method of doubt.

This belief method has two meanings. First, belief relates to reality; belief that is definitely related to the empirical object. Second, scientific belief is related to perceptions of axiomatic truth and theoretical truth.

The tools in science can be used to achieve the belief that there are truths of senses, mind and intuition. If the tool used to believe the truth is mind then that is rationalism. Someone is said to be rationalistic if he tells the truth based on experience. On the other hand, if the tools used to believe the truth are senses and experiences, then that is empiricism.

In the method of doubt, there is a principle that doubting humans is able to know. Wijaya (2017) identified that there are four methods of doubt: absolute doubt, muqallidah doubt, imani doubt, and methodological doubt. Absolute doubt does not believe in the ability of mind and senses as means of knowledge, nor does it reject the existence of truth that can be known through these two tools. Muqallidah doubt is to believe the truth but reject the ability of the mind and senses to know the truth. Imani doubt is to believe that truth can only be known by revelation. Methodological doubt is believing humans may know the truth but they are critical of the knowledge tools that primarily involve senses and mind.

Based on the description above, the researcher assessed that the thought of Iwan Triyuwono is based on methodological doubt. Triyuwono tries to neutralize the senses and mind from the wrong contents and mixed up, so the process of studying the object can be started from the beginning. It can be seen from the attempt of Triyuwono (2000) to perform methodological combination of empiricism and normativism with symbolic interactionism. This methodological combination is from Triyuwono's view that human nature is not limited to physical beings but also spiritual. Such opinion is justified by Islamic values. That Islam gives top priority based on its spiritual level (Triyuwono, 2000). Besides, Islam does not recognize dualism or dichotomy as modern knowledge. Therefore, science makes religion (Islam) to meet the holistic needs of humans (material and spiritual) in order to survive in the world and the hereafter (Triyuwono, 2000).

Triyuwono's doubts about empiricism even normativism can be seen from the following statement:

There is no guarantee that empirical reality always corresponds to normative views. However, using normative reasoning extensively, without seeing and considering or even ignoring empirical reality, will lead to normative ideas that will continually float in the space of imagination and never ground down (Triyuwono, 2000).

Likewise, Triyuwono's attempts to sterilize senses and mind are as follows:

The use of symbolic interactionism as a tool in this study, in which the perspective of Islam is dominant, is actually a manifestation of the inclusive principle from this perspective in its efforts to see reality in broader insight and understanding (Triyuwono, 2000).

His power is spread in the form of verses of qauliyah and verses of kauniyah, which from an epistemological point of view are two sources which must be complementarily used to know His will (Sunnatullah or the will of God); the will expressed in the form of natural, social and spiritual law. It is in this will that true humans bind themselves and submit themselves totally. In other words, true human beings, in their social lives, consciously submit and obey the networks of God's power which are manifested in the form of those laws. To find out about these power networks, humans can use their minds and hearts. Both are God's gifts given to each human being; when they are used in a proportional and balanced measure, they will help humans to find these power networks (Triyuwono, 2012).

On the basis of recognition of the senses, mind and intuition to find the truth, Triyuwono proposed the assumption of tawheed ontology as the basis for viewing reality. (Triyuwono, 2006; Triyuwono, 2012). This tawheed ontology has an impact on human perception as a model of human spirits (Triyuwono 2015) which is derived from the Khalifatullah fil Ardh 
model (Qur'an 2: 30). Khalifatullah fil Ardh is a perspective that is aware of responsibility later in the future in front of Allah Almighty (Triyuwono, 2000).

After establishing his philosophical assumption based on Islamic values, Triyuwono created a concept of sharia accounting using trustworthy metaphors. Islamic accounting began to grow as Ho, Masood, Rehman, \& Bellalah (2012) mention that the amount of interest in Islamic investment and finance cannot be separated from the increasing prosperity of Islamic countries.

This mandate metaphor is derived from the interpretation of QS 2: 282 on the word fair which is the expected value of the concept of sharia accounting (Triyuwono, 2012). The mandate metaphor acts as a tool to realize the mandate of Islamic organizations.

From Islamic philosophical building on Islamic accounting, the Islamic accounting theory was established with the principles of prophetic social science from Kuntowijoyo (2008) who had humanist, emancipatory, transcendental and teleological principles. Humanist gives an understanding that sharia accounting theory is humanistic, in accordance with human nature, and can be practiced according to the capacity possessed by humans as beings who always interact with others (and nature) dynamically in daily life. Emancipatory has the understanding that sharia accounting theory is able to make significant changes to modern accounting theories and practices that exist today. Transcendental means that sharia accounting theory crosses the boundaries of its own accounting discipline, even crossing the boundary of the material (economic) world. Teleology provides a rationale that accounting does not merely provide information for economic decision making, but also has a transcendental purpose as a form of human accountability to God, to fellow human beings, and to the universe (Triyuwono, 2012).

Furthermore, in implementing the sharia accounting building, Triyuwono uses an intuition tool just like the design of Islamic accounting financial statements based on Manunggaling Kawulo Gusti philosophy from Syaikh Siti Jenar. It provokes controversy in the development of Islamic sharia accounting in particular. There are several things that researchers have grasped over the growing controversy. First, Shaykh Siti Jenar himself is a controversial Sufi figure. Based on Chodjim (2002) it was depicted that Syaikh Siti Jenar was considered to have opinions that were not in accordance with public opinion and not even in accordance with the contents of the Qur'an and al-Hadith by the saints of Islam.

There was political charge in the form of the competition between the saints at that time in fighting over the influence on the earth of the archipelago (Chodjim, 2002). Second, the development of Sufism based on the irfani epistemology has not been famous in Indonesia. Irfani's characteristic that recognizes the truth solely based on intuition is often understood as the lowest method of thinking that is irrational and anticritical in reasoning. As a result, Sufism thought by the Sufis loses its critical dimension which is magical as the decline of Muslims glory (Ridwan \& Safrudin, 2011).

Triyuwono actually tried to spread the thought of Shaikh Siti Jenar in accounting. Triyuwono argued that the characteristics of Islamic accounting which are mutually inclusive are in line with the philosophical value of Manunggaling Kawulo Gusti. This philosophical value does not separate something from another (different), but instead combines the form of unity. Differences are dynamic forms that will strengthen unity (Triyuwono, 2012).

Therefore, Triyuwono considered that the interpretive and critical paradigms are not appropriate to cover the sharia accounting building. The postmodern paradigm is considered by Triyuwono as the right paradigm, considering that the postmodern paradigm accepts various thoughts which can be synergized in the form of a whole thought. Manunggaling Kawulo Gusti itself is synergizing two very different things such as between kawulo (human) and gusti (God), masculine and feminine traits, expansive and defensive traits, selfishness and altruistics traits, rational and intuitive traits, objective and subjective traits, material and spiritual, and many more (Triyuwono, 2012).

Intuitive analysis based on Iwan Triyuwono's thinking was carried out with the following steps: (1) exploring the experience of Iwan Triyuwono in developing accounting concepts; (2) summarizing the accounting concepts proposed by Iwan Triyuwono in a reflective 
manner, (3) presenting some accounting concepts as the result of intuitive method by the researchers, and (4) synthesizing.

\section{CONCLUSION}

As explained in the previous sections, the process of lowering 3T thinking into a methodology focused on the figures' way of thinking in developing their thoughts. Each 3T figure could be synthesized as follows: (1) HOS Tjokroaminoto's thinking is in a contextual way; (2) Ibn Taimiyah's thinking is in a literalistic way; and (3) Iwan Triyuwono's thinking is in an intuitive way.

The contextual way of HOS Tjokroaminoto's thought was extracted based on his way of thinking in adopting Marxist socialism that was adapted to Islamic values, especially the Indonesian people who were in the colonial period. On the other hand, the literalistic thought of Ibn Taimiyah tried to restore the purity of the text based on the Qur'an and Hadith. Furthermore, the way Iwan Triyuwono thought was abstracted as an intuitive methodology. The use of intuition as an analytical tool (Ramakrishna, 2018) has an important role in a qualitative research. This intuitive methodology perfects Ibn Taymiyah's literalistic methodology and the contextual methodology of HOS Tjokroaminoto in an effort to penetrate the heart of reality. This is the solution offered as a way to overcome the trap of materialism and homo sociologicus in classic PEA.

\section{REFERENCES}

1. Abdelrehim, N. (2012). Accounting for power and control: The Anglo-Iranian oil nationalisation of 1951. Critical Perspectives on Accounting, 23(7-8), 595-607.

2. Al-Jabiri, M. A. (2003). Formasi Nalar Arab: Kritik Tradisi Menuju Pembebasan and Pluralisme Wacana Interreligius. Yogyakarta: IRCiSod.

3. Amin, M. M. (1995). HOS. Tjokroaminoto: Rekonstruksi Pemikiran and Perjuangan. Yogyakarta: Cokroaminoto University Press.

4. Amin, M. M. (1980). Saham HOS Tjokroaminoto: Dalam Kebangunan Islam and Nasionalisme di Indonesia. Yogyakarta: Penerbit Nur Cahaya.

5. Amir, V., Mulawarman, A. D., Kamayanti, A., \& Irianto. G. (2014). Gugurnya Petani Rakyat: Episode Perang Laba Pertanian Nasional. Malang: Universitas Brawijaya Press.

6. Andrianto, J., \& Irianto, G. (2008). Akuntansi and Kekuasaan: [dalam konteks] Bank BUMN Indonesia. Malang: Aditya Media Publishing.

7. Anshory, N., \& Hendratno, A. (2015). HOS Tjokroaminoto: Pelopor Pejuang, Guru Bangsa and Penggerak Sarikat Islam. Yogyakarta: Penerbit IImu Giri.

8. Bakar, O. (2008). Tauhid \& Sains: Perspektif Islam tentang Agama \& Sains Kedua \& Re. Bandung: Pustaka Hidayah.

9. Burrell, G. (1979). Sociological Paradigms and Organisational Analysis: Elements of the Sociology of Corporate Life. London: Heinemann Educational Books.

10. Chodjim, A. (2002). Syekh Siti Jenar Makna Kematian. Jakarta: PT Serambi IImu Semesta.

11. Cooper, D. (1984). The Value of Corporate Accounting Reports: Arguments for a Political Economy of Accounting. Accounting, Organizations and Society, 9(3/4), 207-232.

12. Faruqi, I. R. (1992). Al Tawhid: Its Implications for Thought and Life. Virginia: International Institute of Islamic Thought.

13. Haryadi, B. (2011). Analisis Laba (Rugi) PDAM Dalam Perspektif Political Economy of Accounting (Unpublished Thesis). Universitas Brawijaya, Malang.

14. Hidayat. (2013). Materialisme Historis. Yogyakarta: Penerbit Pena Hikmah.

15. Ho, C. S. F. (2012). Syariah accounting and compliant screening practices. Qualitative Research in Financial Markets, 4(2/3), 240-254.

16. Irianto, G. (2004). A Critical Enquiry into Privatisation of State-owned Enterprises: Case of PT Semen Gresik (Persero) Tbk (Unpublished Thesis). University of Wollongong, Australia. 
17. Jensen, M. C. (1994). The Nature of Man. Journal of Appied Corporate Finance, 2, 4-19.

18. Kamla, R. (2009). Critical insights into contemporary Islamic accounting. Critical Perspectives on Accounting, 20, 921-932.

19. Kristeva, N. S. S. (2011). Negara Revolusi Marxis and Proletariat. Yogyakarta: Pustaka Pelajar.

20. Kuntowijoyo. (2008). Paradigma Islam: Interpretasi untuk aksi Priyono. Bandung: Penerbit Mizan.

21. Madjid, N. (1984). Ibn Taymiyya on Kalam and Falsafa (Problem of Reason an Revelation in Islam (Unpublished Thesis). University of Chicago, USA.

22. Mauludi, S. (2012). Ibn Taimiyah: Pelopor Kajian Islam yang Kritis. Penerbit Dian Rakyat.

23. Moleong, L. (2008). Metodologi Penelitian Kualitatif. Bandung: PT Remaja Rosdakarya.

24. Mulawarman, A. D. (2015). Jang Oetama: Jejak and Perjuangan H.O.S Tjokroaminoto. Yogyakarta: Penerbit Galang Pustaka.

25. Noch, Y. M. (2013). Analisis Political Economy of Accounting atas Dana Otonomi Khusus Provinsi Papua (Unpublished Thesis). Universitas Brawijaya, Malang.

26. Quthb, S. (1994). Keadilan Sosial Dalam Islam Edisi terj. Bandung: Penerbit Pustaka.

27. Rahardjo, D. (2005). Paradigma Al-quran: Metodologi Tafsir \& Kritik Sosial. Jakarta Pusat: Pusat Studi Agama and Peradapan (PSAP) Muhammadiyah.

28. Ramakrishna, R. A. R. (2018). Using Intuitive Judgment In Qualitative Content Analysis: Implicationa For Research In Varieties of English. International of Business and Society, 19, 262-273.

29. Ridwan, A. H., \& Safrudin, I. (2011). Dasar-dasar Epistemologi Islam. Bandung: CV Pustaka Setia.

30. Roslender, R. (1992). Sociological Perspectives on Modern Accountancy. London-New York: Roudledge.

31. Rosser, A. (1999). The Political Economy of Accounting Reform In Developing Countries: The Case of Indonesia (Unpublished Thesis). Murdoch University, Perth.

32. Shaoul, J. (1997a). A Critical Financial Analysis of the Performance of Privatised Industries: The Case of the Water Industry in England and Wales. Critical Perspectives on Accounting, 8, 479-505.

33. Shaoul, J. (2003). A critical financial analysis of the Private Finance Initiative: selecting a financing method or allocating economic wealth? Critical Perspectives on Accounting, 16(4), 441-471.

34. Shaoul, J. (1997b). The Power of Accounting Reflecting on Water Privatization. Accounting, Auditing \& Accountability Journal, 2, 382-405.

35. Sokarina, A. (2011). Analisis Kritis Kinerja Pra and Pascaprivatisasi dari Perspektif Political Economy of Accounting (Studi pada PT Telkom Tbk and PT Indosat Tbk) (Unpublished Thesis). Universitas Brawijaya, Malang.

36. Souza, R. (2007). Classical Marxism, Socialism, and the Market. Nature, Society, and Thought, 20(3-4), 438-444.

37. Suseno, F. M. (2010). Pemikiran Karl Marx: Dari Sosialisme Utopis ke Perselisihan Revisionisme. Jakarta: Percetakan PT SUN.

38. Tinker, A. M. (1982). The normative origins of positive theories: Ideology and accounting thought. Accounting, Organizations and Society, 7(2), 167-200.

39. Tjokroaminoto, H. (2010). Islam and Sosialisme. Bandung: Sega Arsy.

40. Triyuwono, I. (2006). Akuntansi Syari'ah: Perspektif, Metodologi, and Teori. Jakarta.

41. Triyuwono, I. (2012). Akuntansi Syariah: Perspektif, Metodologi, and Teori. Jakarta: PT Grajafindo Persada.

42. Triyuwono, I. (2015). Awakening the conscience inside: the spirituality of code of ethics for professional accountants. Procedia - Social and Behavioral Sciences, 172, 254-261.

43. Triyuwono, I. (2000). Organisasi and Akuntansi Syari'ah. Yogyakarta: LKiS.

44. Uddin, S., \& Hopper, T. (2003). Accounting For Privatisation In Bangladesh. World Bank Claims, 14, 739-774.

45. Wijaya, A. (2017). Nalar Kritis Epistemologi Islam. Yogyakarta: Kalimedia. 